\title{
Population abundances, growth and natural mortality of the crustacean macroinfauna at two sand beach morphodynamic types in southern Chile
}

\author{
Abundancias poblacionales, crecimiento y mortalidad natural de la macroinfauna de \\ crustáceos en dos tipos morfodinámicos de playas arenosas del sur de Chile
}

\author{
HERALDO CONTRERAS ${ }^{1,2}$, EDUARDO JARAMILLO ${ }^{1}$, CRISTIAN DUARTE $^{1} \&$ ANTON MCLACHLAN $^{3}$ \\ ${ }^{1}$ Instituto de Zoología, Universidad Austral de Chile, Valdivia, Chile; \\ 2e-mail: hcontreras@uach.cl \\ ${ }^{3}$ College of Science, Sultan Qaboos University, Oman
}

\begin{abstract}
Monthly samplings were carried out during 1994-1996 at an intermediate and at a dissipative sandy beaches of southern Chile (Calfuco and Mehuín, respectively; ca. $39^{\circ} \mathrm{S}$ ), to evaluate the predictions of the swash exclusion hypothesis on the population abundances and life history of the crustacean macroinfauna inhabiting the intertidal of that beaches. It is hypothesized that only true intertidal species (i.e., that directly affected by the swash) will be affected by differences in beach morphodynamic types. That species were the cirolanid isopods Excirolana braziliensis and Excirolana hirsuticauda and the anomuran crab Emerita analoga. On the other hand, the almost supralittoral amphipod Orchestoidea tuberculata should not be affected by differences in beach morphodynamic types. The total population abundances of $O$. tuberculata and E. analoga were significantly higher at the intermediate beach of Calfuco, that of E. braziliensis and E. hirsuticauda at the dissipative beach of Mehuín. While the abundances of ovigerous females of $O$. tuberculata and E. analoga were higher at Calfuco, that of the ovigerous females of E. braziliensis and $E$. hirsuticauda did not differ between beaches. Juveniles of $O$. tuberculata had higher abundances at Calfuco, while that of the other species peaked at Mehuín. The reproductive period of amphipods and isopods peaked at the same spring-summer months at both beaches. E. analoga also reproduced during springsummer months, but their abundances peaked at different months. While juveniles of $O$. tuberculata peaked at similar times at both beaches, those of Excirolana braziliensis and E. hirsuticauda peaked later at Mehuín. Juveniles of E. analoga had very low abundances during the first spring-summer period of this study; during the second one they peaked at the same month (October) at both beaches. The growth curves and growth parameters of $O$. tuberculata, E. braziliensis and E. hirsuticauda did not differ significantly between beaches, even when $O$. tuberculata tended to growth faster at Calfuco. The growth curves and growth parameters for E. analoga were different only for females, which had higher growth at the dissipative site. The natural mortality of the four species showed no significant differences between beaches. Thus, most of the results of this study do not support our hypothesis, suggesting that other factors, apart from beach morphodynamics are important in explaining spatial variability in population abundances and population biology of the sandy beach macroinfauna.
\end{abstract}

Key words: sandy beach macroinfauna, crustaceans, beach morphodynamic types, southern Chile.

\section{RESUMEN}

Se realizaron muestreos mensuales durante 1994-1996 en una playa arenosa intermedia y en una playa disipativa del sur de Chile (Calfuco y Mehuín, respectivamente; ca. $39^{\circ} \mathrm{S}$ ), para evaluar las predicciones de la hipótesis de exclusión por la resaca sobre las abundancias poblacionales e historia de vida de la macroinfauna de crustáceos que habita en el intermareal de esas playas. Se hipotetiza que solo las especies realmente intermareales (i.e., directamente afectadas por la resaca) son afectadas por diferencias en los tipos morfodinámicos de playas. Esas especies fueron los isópodos cirolánidos Excirolana braziliensis y Excirolana hirsuticauda y el cangrejo anomuro Emerita analoga. Por otra parte, el anfípodo Orchestoidea tuberculata (mayoritariamente supralitoral) no debiera ser afectado por diferencias en tipos morfodinámicos de playas. Las abundancias poblacionales totales de $O$. tuberculata y E. analoga fueron significativamente más altas en la playa intermedia de Calfuco, las de E. braziliensis y E. hirsuticauda en la playa disipativa de Mehuín. Mientras que las abundancias de las hembras ovígeras de $O$. tuberculata y E. analoga fueron más altas en Calfuco, las de las hembras ovígeras de E. braziliensis y E. hirsuticauda no difirieron entre playas. Los juveniles de $O$. tuberculata fueron más abundantes en Calfuco, mientras que los de las otras especies en 
Calfuco. Los máximos en los períodos reproductivos de anfípodos e isópodos ocurrieron durante los mismos meses de primavera-verano en ambas playas. El período reproductivo de E. analoga también ocurrió durante primavera-verano, pero los máximos de abundancia ocurrieron en meses diferentes. Mientras que las máximas abundancias de los juveniles de $O$. tuberculata ocurrieron en períodos similares, las de los juveniles de Excirolana braziliensis y E. hirsuticauda ocurrieron más tarde en Mehuín. Los juveniles de E. analoga tuvieron abundancias muy bajas durante el primer período primavera-verano; durante el segundo, mostraron sus máximas abundancias durante octubre en ambas playas. Las curvas de crecimiento y parámetros de crecimiento de $O$. tuberculata, E. braziliensis y E. hirsuticauda no difirieron significativamente entre playas, aun cuando $O$. tuberculata tendió a crecer más rápido en Calfuco. Las curvas de crecimiento y parámetros de crecimiento de E. analoga fueron diferentes solo para las hembras, las que tuvieron mayor crecimiento en el sitio disipativo. Las mortalidades naturales de las cuatro especies no difirieron significativamente entre playas. Así, la mayoría de nuestros resultados no soportan nuestra hipótesis, sugiriendo que otros factores, aparte de las morfodinámica de la playa, son importantes en explicar la variabilidad espacial en las abundancias poblacionales y biología poblacional de la macroinfauna de playas arenosas.

Palabras clave: macroinfauna de playas arenosas, crustáceos, tipos morfodinámicos de playas, sur de Chile.

\section{INTRODUCTION}

In recent years it has been shown that the community structure of sand beach macroinfauna from several coasts is related to beach morphodynamics; i.e., species richness, abundance and biomass of the macroinfauna usually increase from reflective to dissipative beaches (see review in McLachlan \& Jaramillo 1995). It was argued that swash features associated with beach types had a significant effect on the macroinfauna, this idea being referred to as the swash control hypothesis (McLachlan 1990). Later, this was modified to the swash exclusion hypothesis (McLachlan et al. 1993), which stated that swash features become more harsh from dissipative to reflective conditions; thus, in fully reflective beaches only supralittoral species are found buried into the sands, since that sediments are above the beach face directly exposed to the swash (McLachlan et al. 1993).

Several studies have analysed the predictions of the swash exclusion hypothesis. McLachlan et al. (1995) showed that shell shape and density of bivalves varied along a gradient of beach types: those inhabiting reflective sites were small, wedge-shaped and of high density as compared with those from more dissipative beaches which varied widely in that characteristics but tended to be larger and less dense. It was concluded that small size and high density were key adaptations to the harshest beaches, i.e., reflective systems with turbulent swash and coarse sand (McLachlan et al. 1995). Jaramillo et al. (2000) compared two populations of the sand crab Emerita analoga (Stimpson) in two sandy beaches of south central Chile and found higher population abundances, larger body sizes and a wider tidal migration at a dissipative site, as compared to a reflective one. Jaramillo \& McLachlan (1993) found that population abundances of Excirolana braziliensis (Richardson) (Isopoda, Cirolanidae), Orchestoidea tuberculata Nicolet (Amphipoda, Talitridae) and E. analoga increased towards the dissipative extreme of sandy beaches in south central Chile. They also found that the body sizes of E. braziliensis and $E$. analoga increased along the same gradient. Recently, Gómez \& Defeo (1999), Defeo et al (2001) and Defeo \& Martínez (2003), tested differences in reproductive sizes, fecundity, individual growth and mortality rates of several crustacean species of Uruguayan sandy beaches with contrasting morphodinamics features, finding that these aspects of life history were not fully explained in terms of beach morphodinamics.

The crustacean macroinfauna of sandy beaches located in southern Chile (ca. 35-42 ${ }^{\circ} \mathrm{S}$ ) is typically represented by the amphipod Orchestoidea tuberculata, the isopods Excirolana braziliensis and Excirolana hirsuticauda and the anomuran crab Emerita analoga. Several studies have described the zonation pattern of these species, with the upper shore $O$. tuberculata buried around and above the drift line, E. braziliensis and E. hirsuticauda mostly buried at the mid shore levels (retention zone), and $E$. analoga typically found at the lower shore levels or swash zone (Jaramillo 1994, 2001). While population abundances differ, these four species are nevertheless found coexisting on different morphodynamic beach types in south central Chile as in other areas further north along the Chilean coast (e.g., Jaramillo et al. 1998). Since different swash features are associated with different beach morphodynamic types (cf. McArdle \& 
McLachlan 1991, 1992), the above mentioned coexistence provides an opportunity to test whether differences in beach types cause differences in population attributes of these species. Thus, we hypothesize that only true intertidal species inhabiting different beach types, will differ in their population abundances and life history characteristics. On the other hand, almost supralittoral organisms $(O$. tuberculata) will not be affected by differences in beach morphodynamic types. The true intertidal species (i.e. that directly affected by the swash) include the isopods $E$. braziliensis, $E$. hirsuticauda and the sand crab E. analoga. The isopods disperse into the water when swash reach their burrowing zone (Jaramillo \& Fuentealba 1993, Kennedy 1997) and E. analoga migrates up and down the shore following changes in tides (Jaramillo et al. 2000).

\section{MATERIAL AND METHODS}

\section{Study area}

The beaches studied, Mehuín (ca. 39 $26^{\prime} \mathrm{S}$, $73^{\circ} 13^{\prime} \mathrm{W}$ ) and Calfuco (ca. 39 $41^{\prime} \mathrm{S}, 73^{\circ} 23^{\prime}$ $\mathrm{W})$ are located on the coast near Valdivia, southern Chile. These beaches are about $2 \mathrm{~km}$ and $1 \mathrm{~km}$ long, respectively. Both are microtidal beaches with maximum tide ranges close to $1.5 \mathrm{~m}$. Snapshot studies carried out during the fall of 1991 and the summer of 1994, show that Mehuín is a dissipative beach, while Calfuco is an intermediate beach (Jaramillo \& McLachlan 1993, Ramírez 1994). Swash features associated to each beach were shown to be different by Ramírez (1994); thus, while the beach zone affected by the swashes was wider at Mehuín ( 20-35 versus $\sim 5-12 \mathrm{~m}$ at Calfuco), the number of upswash crossings above the effluent line in a period of 10 minutes was higher at the intermediate beach of Calfuco ( 10-20) as compared with Mehuín ( 3.5-5 crossings).

\section{Physical measurements}

The morphodynamic characteristics of both beaches were studied during October and December 1994 and February, March, May, September and October 1995. The morphology of each sampling site (i.e., beach face slope) was determined by Emery's profiling technique (Emery 1961). Sediment samples for grain size analysis were collected from the lowest swash level with a $3.5 \mathrm{~cm}$ diameter plastic cylinder driven to an approximate depth of $5 \mathrm{~cm}$. Those analyses were carried out using a settling tube (Emery 1938). Mean grain size was calculated according to the moments computational method (Seward-Thompson \& Hails 1973) and used to estimate sand fall velocity according to the method described by Gibbs et al. (1971). Wave height was estimated by measuring the height of breaking waves with graduated poles against the horizon, and adding the result to the height difference between the location of the observer and the lowest point where the backwash met the incoming swash bore. The wave period (measured with a stop watch) was the time interval between breaking waves. From estimated mean wave height, wave period and sand fall velocity, Dean's parameter $(\Omega)$ (Short \& Wright 1983) was calculated.

\section{Sampling of macroinfauna}

Sediment samples were collected from October 1994 through March 1996. The samples were collected with plastic cylinders $(25 \mathrm{~cm}$ in diameter) at ten equally spaced levels (stations) along six replicated transects ( $1 \mathrm{~m}$ apart) extending from above the drift line to the swash zone; i.e., the uppermost station of each transect was located above the drift line, the second on the drift line and the last at the lowest limit of the swash zone (indicated by bore collapse). The sediment was sieved through $1 \mathrm{~mm}$ mesh and the specimens preserved in $5 \%$ formalin until sorting.

\section{Data analyses}

One-way ANOVA was used to compare physical characteristics between beaches. Normality and homocedasticity were tested with the Kolmogorov-Smirnov's and Bartlett's tests, respectively (Sokal \& Rohlf 1995). Those tests showed that grain size values had significant departures from those basic assumptions; thus, those values were transformed by the expression $\log (n+1)$.

Abundance values per running meter of beach were obtained by linear interpolation between sampling stations, after obtaining mean abundances per $\mathrm{m}^{2}$ at each sampling station. Two-way ANOVA (beaches and months as factors) was used to compare total population abundances and abundances of ovigerous females and juveniles of $O$. tuberculata, E. braziliensis, E. hirsuticauda and E. analoga (ind $\mathrm{m}^{-1}$ ). Normality and homocedasticity were tested with the Kolmogorov-Smirnov's and Bartlett's tests, respectively (Sokal \& Rohlf 1995). Since those 
tests showed some significant departures from that basic assumptions; the abundance data were transformed by the expression $\log (\mathrm{n}+1)$.

Body sizes of $O$. tuberculata, E. braziliensis, E. hirsuticauda and E. analoga were obtained for growth analyses. For the amphipod, body length was defined as the distance from rostrum tip to telson base, whereas in the isopods, body length was defined as the distance from rostrum tip to telson tip. The cephalothorax length of $E$. analoga was used as a measure of body size. We counted the number of ovigerous females and juveniles of all the species. Sexes in Orchestoidea and Excirolana were distinguished on the basis of the study of Jaramillo (1987). Specimens lacking ooestegites, penes and male appendices were considered juveniles. Sexes of $E$. analoga were distinguished on the basis of anatomical studies carried out by Knox \& Boolotian (1963), Osorio et al. (1967) and Penchaszadeh (1971) on species of the genus Emerita. Thus, apart from the fact that males reach smaller sizes than females (Osorio et al. 1967), females are recognized by the presence of pleopods on the second, third and fourth abdominal somites and the genital pore located on the coxopodite of the third walking leg, while males lack pleopods and the genital pore is located on a papilla on the coxopodite of the fifth walking leg (Knox \& Boolotian 1963). Specimens lacking that characteristics were considered juveniles.

Due to the notorious differences in body sizes of males and females in E. analoga we discriminated by sex for body size measurements and growth analyses. To test for eventual differences between body sizes of males and females of amphipods and isopods, we compared length frequency distributions with the Kolmogorov Smirnov's test (Sokal \& Rohlf 1995). Since most of the analyses did not render significant differences between sexes, growth analyses of isopods and amphipods were carried out with both sex combined. Size class intervals of $1 \mathrm{~mm}$ were chosen for amphipods, isopods and males of E. analoga, while size class intervals of $2 \mathrm{~mm}$ were chosen for females of $E$. analoga following the criteria of Wolff (1989) and Sparre (1989). We followed the suggestions given for both authors to avoid subjection of growth analyses based only on length-frequency; i.e., (i) analyses of the relation between maximum length observed and the probable modes present in the monthly length frequency data, (ii) use of the smallest practical interval size, and (iii) analyses of length frequency data with a suite of alternative groupings. Thus, we used that suggestions and our own personal experience with similar studies to choose the class intervals mentioned above.

Individual growth rates of $O$. tuberculata, E. braziliensis, E. hirsuticauda and E. analoga (males and females) were determined by analyzing the monthly length frequency distribution. The normal component of each sample was separated with the routine NORMSEP included in the software FISAT (Gayanilo et al. 1996). This analysis allowed identification of means and standard deviations of each cohort. An age-body size key for each population was obtained following the methodology of Gómez \& Defeo (1999). Each cohort was followed over time; a value of absolute age was assigned to each cohort (from time zero or birth). Time zero was defined as minimum size of recruits $(3 \mathrm{~mm}$ for amphipods and isopods and $4 \mathrm{~mm}$ for males and females of E. $\operatorname{ana} \log a$ ). The results were fitted to the von Bertalanffy growth function (VBGF) with seasonal oscillation (Hoenig \& Hanumara 1982; Sommers 1988):

$$
\begin{gathered}
\mathrm{L}_{\mathrm{t}}=\mathrm{L}_{\infty}\left[1-\mathrm{e}\left[-\mathrm{K}\left(\mathrm{t}-\mathrm{t}_{0}\right)+(\mathrm{KC} / 2 \mathrm{p}) \sin 2 \mathrm{p}\right.\right. \\
\left.\left.(\mathrm{t}-\mathrm{WP})-(\mathrm{KC} / 2 \mathrm{p}) \sin 2 \mathrm{p}\left(\mathrm{t}_{0}-\mathrm{WP}\right)\right]\right]
\end{gathered}
$$

where $L_{t}$ is the length at age $t, L_{\infty}$ is the asymptotic length, $\mathrm{K}$ is the curvature parameter, $\mathrm{t}_{0}$ is the computed age at length zero, $\mathrm{C}$ is the parameter reflecting the intensity of seasonal growth oscillation, and winter point (WP) was defined as the time (expressed as a decimal fraction of the year) when growth is slowest (Pauly \& Gaschütz 1979). The parameters of VBGF were estimated with a non linear method of optimization by using the MarquardtLevenberg algorithm included in the software Sigmaplot (Marquardt 1963, Shrager 1972, Nash, 1979, Ress et al. 1986). An analyses of the residual sum of squares (ARSS) was employed to compare the VBGF between populations. The Fstatistic was calculated as Chen et al. (1992) (Gómez \& Defeo 1999, Defeo et al. 2001).

$$
\mathrm{F}=\frac{\frac{\mathrm{RSSp}-\mathrm{RSSs}}{3 \times(\mathrm{K}-1)}}{\frac{\mathrm{RSSs}}{\mathrm{N}-3 \times \mathrm{K}}}
$$

where RSSp is the residual sums of square (RSS) of the VBGF fitted by pooled data (samples from both population pooled), RSSs is the sum of the RSS of each VBGF fitted to each population, $\mathrm{K}$ is the number of samples in the comparison, and $\mathrm{N}$ is the total sample size. The calculated $\mathrm{F}$ value was then compared with the critical F, with $3 \times(\mathrm{K}-1)$ and $\mathrm{N}-3 \times \mathrm{K}$, 
degrees of freedom for the numerator and denominator, respectively.

To compare different growth rate estimates, the standard growth index F' (phi prime: Pauly \& Munro 1984, Vakily 1990) was employed as a measure of overall growth performance (Sparre et al. 1989). This rationale provides a unified parameter of growth performance which does not show large variations as do $\mathrm{K}$ and $\mathrm{L} \infty$ values and it has been used frequently in similar studies (Contreras et al. 2000, Gómez \& Defeo 1999, Defeo et al. 2001).

$$
\mathrm{F}^{\prime}=2 \log _{10}\left(\mathrm{~L}_{\infty}\right)+\log _{10} \mathrm{~K}
$$

The instantaneous rate of natural mortality (M) of each population was estimated by lengthconverted catch curves and growth parameters estimated with the equation given by Pauly et al. (1995), for species which have growth with seasonal oscillation (i.e., when $\mathrm{C}>0$, Gayanilo et al. 1996):

$$
\ln (\mathrm{N})=\mathrm{a}-\mathrm{b} \times \mathrm{t}^{\prime}
$$

where $\mathrm{N}$ is the number of individuals in a pseudo-cohort "sliced" by means of sucessive growth curves, t' the relative age of individuals in the pseudocohort, $a$ is the regressión intercept and $b$ (with sign changed), provides an estimate of M (cf. Pauly et al. 1995, Gayanilo et al. 1996, Gómez \& Defeo 1999, Defeo et al. 2001). This equation gives an estimate of total mortality (Z); and since the species studied do not have fishing mortality (F), then $Z=M$. To carry out that regressions, the extreme points of the distributions (i.e. the smallest and largest sizes) were excluded from the analyses (cf. Sparre \& Venema 1995). We followed that procedure since that points did not fit into a straight line; moreover, in most cases, the smallest size classes did not represent a full recruitment and the largest size classes were very close to the values of Lo (cf. Sparre \& Venema 1995). An ANCOVA was used to compare the slopes (i.e. mortality) of the linear regressions between the crustacean populations of Calfuco and Mehuín, using age as the covariate.

\section{RESULTS}

\section{Beach characteristics}

Table 1 shows the values of the physical characteristics of both beaches during each sampling date and the total mean for each variable; Table 2 shows the results of ANOVA aimed to examine if that total means differed between beaches. The intertidal zone (distance between the drift line and the lowest swash level) was significantly wider at Mehuín (total mean: $83 \mathrm{~m}$ ) as compared with Calfuco (total mean: $47 \mathrm{~m})(\mathrm{P}=0.002$, Table 2$)$. The intertidal of Calfuco was always steeper than that of Mehuín (total mean 1/17 versus 1/31); thus, total means from each beach were significantly different $(\mathrm{P}=0.014$, Table 2$)$. During all the sampling period, the sands of the lowest swash level of Calfuco were in the range of medium sands $(250-500 \mu \mathrm{m}$, after Folk 1980), while those of Mehuín were mostly fine sands (125-250 $\mu \mathrm{m}$, after Folk 1980); total means of grain sizes for Calfuco and Mehuín (344 and $247 \mu \mathrm{m}$, respectively) were significantly different $(\mathrm{P}<0.001$, Table 2$)$. Values of wave heights and periods were in similar ranges during the study period; thus, total means between beaches were not significantly different $(\mathrm{P}=0.436$ and 0.160 for wave height and period, respectively, Table 2). Based on the values of Dean's parameter (W), the beach of Calfuco can be classified as intermediate and that of Mehuín as dissipative (sensu Short \& Wright 1983); total means of Dean's parameter differed significantly between beaches $(P=0.016$, Table 2). Thus, differences in morphodynamics are mainly due to differences in grain size.

\section{Total population abundances}

Even when most of the highest values of population abundances occurred primarily during spring-summer months, abundance peaks were also observed during winter (e.g., $O$. tuberculata and E. braziliensis during June and July 1995, respectively) (Fig. 1). The total mean abundance of the talitrid amphipod $O$. tuberculata (i.e., the mean estimated from the whole number of samplings at each beach) was significantly higher $(\mathrm{P}=0.0001$, Table 3$)$ at the beach of Calfuco; 8,401 versus 3,723 ind $\mathrm{m}^{-1}$ at Mehuín. On the other hand, the total mean abundances of the cirolanid isopods $E$. braziliensis and E. hirsuticauda were significantly higher $(\mathrm{P}<0.0001$, Table 3$)$ at Mehuín: 4,052 and 4,147 ind $\mathrm{m}^{-1}$ versus 426 and 3,119 ind $\mathrm{m}^{-1}$ at Calfuco, respectively. The total mean abundance of the anomuran crab $E$. analoga was significantly higher at Calfuco (P $<0.0001$, Table 3) with 38,227 ind $\mathrm{m}^{-1}$ as compared with a total mean abundance of 29,704 ind $\mathrm{m}^{-1}$ at Mehuín. Thus, the results of 


\title{
TABLE 1
}

Temporal variability in the intertidal width, beach face slope, mean grain size of sands from the lowest swash level, wave characteristics and Dean's parameter (W) at the two beaches studied. All the values, except Dean's parameter, were rounded to whole numbers. Values of standard deviations are given for wave height and periods

\begin{abstract}
Variabilidad temporal del ancho intermareal, pendiente de la playa, tamaño medio de la arena en el nivel inferior de la zona de lavado de la ola, características de la ola y parámetro de Dean (W) de las dos playas estudiadas. Todos los valores, excepto parámetro de Dean, fueron aproximados a números enteros.
\end{abstract} Se entregan los valores de la desviación estándar de la altura y periodo de las olas

\begin{tabular}{|c|c|c|c|c|c|c|}
\hline & $\begin{array}{l}\text { Intertidal } \\
\text { width }(\mathrm{m})\end{array}$ & 1/slope & $\begin{array}{l}\text { Mean grain } \\
\text { size }(\mu \mathrm{m})\end{array}$ & $\begin{array}{l}\text { Wave height } \\
(\mathrm{m})\end{array}$ & $\begin{array}{c}\text { Wave period } \\
\text { (s) }\end{array}$ & W \\
\hline \multicolumn{7}{|l|}{ Calfuco } \\
\hline October 1994 & 48 & 15 & 379 & $227(6)$ & $9(3)$ & 4.4 \\
\hline December 1994 & 52 & 16 & 437 & $355(9)$ & $8(3)$ & 7.1 \\
\hline February 1995 & 25 & 8 & 280 & $272(22)$ & $13(3)$ & 5.8 \\
\hline March 1995 & 36 & 14 & 361 & $167(5)$ & $13(3)$ & 2.4 \\
\hline May 1995 & 40 & 16 & 361 & $200(8)$ & $11(1)$ & 3.5 \\
\hline September 1995 & 56 & 12 & 302 & $266(10)$ & $13(2)$ & 5.0 \\
\hline October 1995 & 72 & 38 & 288 & $191(9)$ & $12(2)$ & 4.5 \\
\hline Total mean & $47(15)$ & $17(10)$ & $344(57)$ & $240(64)$ & $11(2)$ & $4.7(1.5)$ \\
\hline \multicolumn{7}{|l|}{ Mehuín } \\
\hline October 1994 & 64 & 31 & 258 & $239(10)$ & $12(6)$ & 6.1 \\
\hline December 1994 & 80 & 26 & 243 & $271(4)$ & $13(4)$ & 7.2 \\
\hline February 1995 & 60 & 28 & 247 & $237(6)$ & $11(3)$ & 6.7 \\
\hline March 1995 & 112 & 37 & 223 & $252(13)$ & $15(5)$ & 6.2 \\
\hline May 1995 & 80 & 23 & 231 & $391(13)$ & $16(3)$ & 8.4 \\
\hline September 1995 & 96 & 24 & 254 & $204(9)$ & $12(3)$ & 5.1 \\
\hline October 1995 & 88 & 45 & 273 & $270(20)$ & $11(3)$ & 6.6 \\
\hline Total mean & $83(18)$ & $31(8)$ & $247(17)$ & $266(60)$ & $13(2)$ & $6.6(1.0)$ \\
\hline
\end{tabular}

TABLE 2

Results of the analyses of variance carried out to test for differences in the physical characteristics of the beaches at Calfuco and Mehuín

Resultados de los análisis de varianza llevados a cabo para evaluar diferencias en las características físicas de las playas de Calfuco y Mehuín

\begin{tabular}{|c|c|c|c|c|}
\hline Source of variation & Degree of freedom & Mean of squares & F-ratio & P-value \\
\hline \multicolumn{5}{|l|}{ Intertidal width (m) } \\
\hline Between groups & 1 & $4,500.07$ & 16.22 & 0.002 \\
\hline Within groups & 12 & 277.41 & & \\
\hline Total & 13 & & & \\
\hline \multicolumn{5}{|l|}{ 1/slope } \\
\hline Between groups & 1 & 644.64 & 8.23 & 0.014 \\
\hline Within groups & 12 & 78.31 & & \\
\hline Total & 13 & & & \\
\hline \multicolumn{5}{|l|}{ Mean grain size $(\mu \mathrm{m})$} \\
\hline Between groups & 1 & 0.36 & 22.96 & 0.000 \\
\hline Within groups & 12 & 0.02 & & \\
\hline Total & 13 & & & \\
\hline \multicolumn{5}{|l|}{ Wave height $(\mathrm{cm})$} \\
\hline Between groups & 1 & $2,471.14$ & 0.65 & 0.436 \\
\hline Within groups & 12 & $3,808.24$ & & \\
\hline Total & 13 & & & \\
\hline \multicolumn{5}{|l|}{ Wave period (s) } \\
\hline Between groups & 1 & 8.64 & 2.24 & 0.160 \\
\hline Within groups & 12 & 3.86 & & \\
\hline Total & 13 & & & \\
\hline \multicolumn{5}{|l|}{$\mathrm{W}$} \\
\hline Between groups & 1 & 13.21 & 7.86 & 0.016 \\
\hline Within groups & 12 & 1.68 & & \\
\hline Total & 13 & & & \\
\hline
\end{tabular}



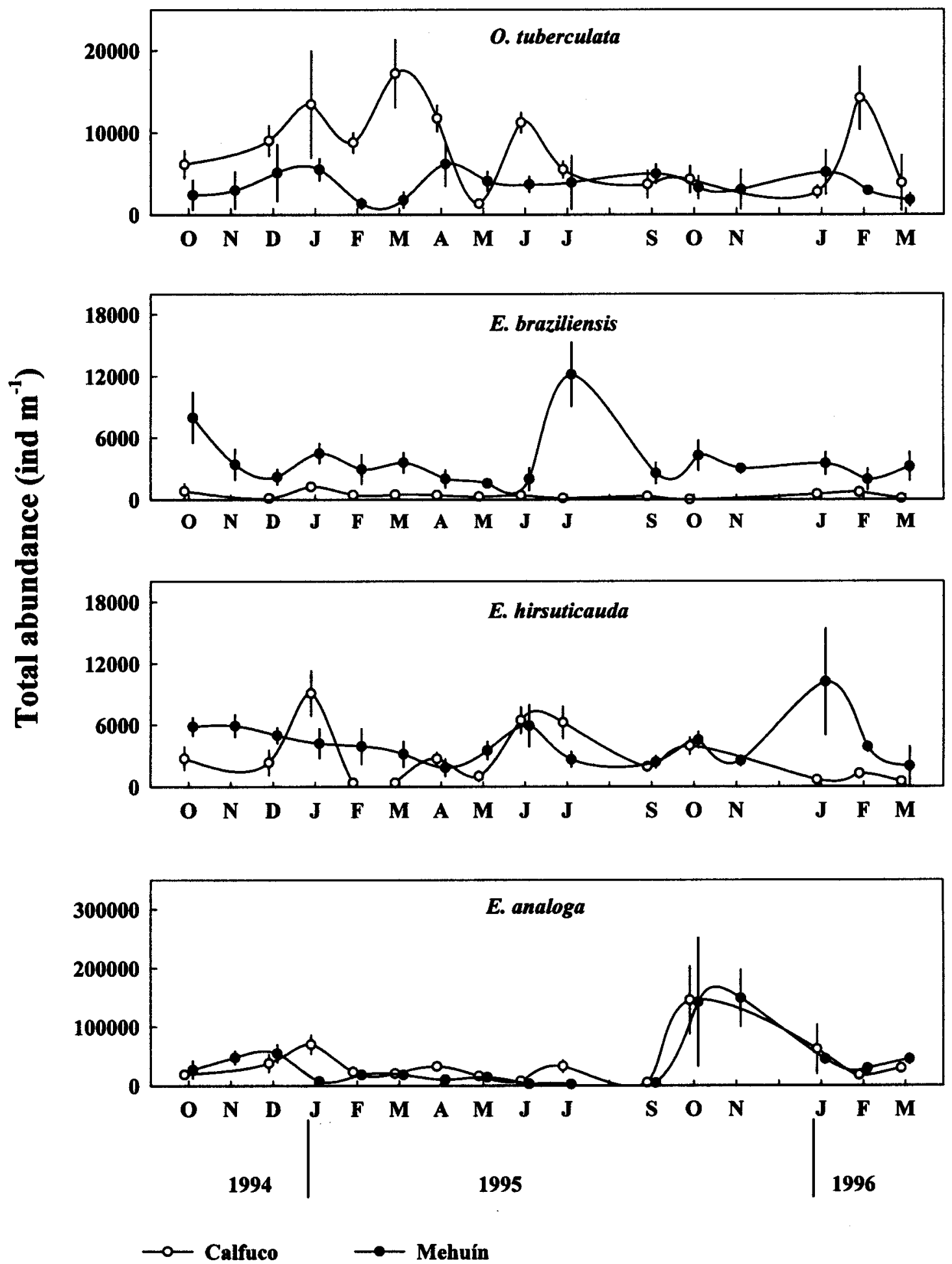

Fig. 1: Temporal variability in total population abundances of O. tuberculata, E. braziliensis, E. hirsuticauda and E. analoga at the beaches of Calfuco and Mehuín. The values are means \pm SD.

Variabilidad temporal en las abundancias poblacionales totales de O. tuberculata, E. braziliensis, E. hirsuticauda y E. analoga en las playas de Calfuco y Mehuín. Los valores son promedios \pm DE. 
TABLE 3

Results of the two-way analysis of variance carried out to test for differences in populations abundances of $O$. tuberculata E. braziliensis, E. hirsuticauda and E. analoga at the beaches of Calfuco and Mehuín

Resultados de los análisis de varianza de dos vías realizados para evaluar diferencias en las abundancias poblacionales de O. tuberculata E. braziliensis, E. hirsuticauda y E. analoga en las playas de Calfuco y Mehuín

\begin{tabular}{|c|c|c|c|c|}
\hline & Degree of freedom & Mean of squares & F-ratio & P-value \\
\hline \multicolumn{5}{|l|}{ O. tuberculata } \\
\hline Beach & 1 & 1.77 & 15.88 & 0.0001 \\
\hline Months & 13 & 0.59 & 5.31 & 0.0000 \\
\hline Beach $\mathrm{x}$ months & 13 & 0.56 & 5.05 & 0.0000 \\
\hline Error & 116 & 0.11 & & \\
\hline \multicolumn{5}{|l|}{ E. braziliensis } \\
\hline Beach & 1 & 2.20 & 73.57 & 0.0000 \\
\hline Months & 13 & 1.01 & 33.75 & 0.0000 \\
\hline Beach $x$ months & 13 & 0.59 & 19.76 & 0.0000 \\
\hline Error & 116 & 0.03 & & \\
\hline \multicolumn{5}{|l|}{ E. hirsuticauda } \\
\hline Beach & 1 & 65.30 & 227.96 & 0.0000 \\
\hline Months & 13 & 2.11 & 7.37 & 0.0000 \\
\hline Beach $\times$ months & 13 & 1.77 & 6.17 & 0.0000 \\
\hline Error & 116 & 0.29 & & \\
\hline \multicolumn{5}{|l|}{ E. analoga } \\
\hline Beach & 1 & 1.70 & 37.77 & 0.0000 \\
\hline Months & 13 & 1.57 & 34.87 & 0.0000 \\
\hline Beach $x$ months & 13 & 0.60 & 13.35 & 0.0000 \\
\hline Error & 116 & 0.04 & & \\
\hline
\end{tabular}

the two-way ANOVA's showed that the population abundances of $O$. tuberculata, $E$. braziliensis, E. hirsuticauda and $E$ analoga varied significantly with beaches and time (months); we also detected significant interactions between month of sampling and beach sampled for each species (Table 3 ).

\section{Reproductive period}

The reproductive period of $O$. tuberculata, $E$. braziliensis, E. hirsuticauda and E. analoga (deduced from the abundances of ovigerous females) occurred during spring-summer months (October till March) (Fig. 2). The total mean abundance of ovigerous females of $O$. tuberculata was significantly higher $(\mathrm{P}=$ 0.0040, Table 4) at Calfuco (163 ind $\left.\mathrm{m}^{-1}\right)$ as compared with Mehuín (44 ind $\mathrm{m}^{-1}$ ). On the other hand, the total mean abundances of ovigerous females of E. braziliensis and $E$. hirsuticauda were not significantly different ( $\mathrm{P}$ $=0.2660$ and 0.9488 , respectively, Table 4) between beaches (70 and 134 ind $\mathrm{m}^{-1}$ versus 15 and 153 ind $\mathrm{m}^{-1}$ at Mehuin and Calfuco, respectively). The total mean abundances of ovigerous females of E. analoga was significantly higher $(P=0.0202$, Table 4$)$ at Calfuco (307 ind $\mathrm{m}^{-1}$ ) as compared with Mehuín (198 ind $\mathrm{m}^{-1}$ ). The results of the twoway ANOVA's showed that the abundances of ovigerous females of $O$. tuberculata and $E$. analoga varied significantly with beaches and time (months) (Table 4). On the other hand, abundances of ovigerous females of $E$. braziliensis and E. hirsuticauda varied significantly with time but not with beaches (Table 4). Significant interactions between month of sampling and beach sampled were detected for the abundances of ovigerous females of all the species except to $O$. tuberculata (Table 4).

Juveniles of $O$. tuberculata, E. braziliensis and E. hirsuticauda usually had their highest abundances 1-2 months after the peaks of ovigerous females (Fig. 2 and 3). While juveniles of $O$. tuberculata peaked at similar times at both beaches, those of E. braziliensis and $E$. hirsuticauda peaked later at Mehuín (Fig. 3). Juveniles of E. analoga had very low abundances during the first spring-summer period of this study; during the second one they peaked during 

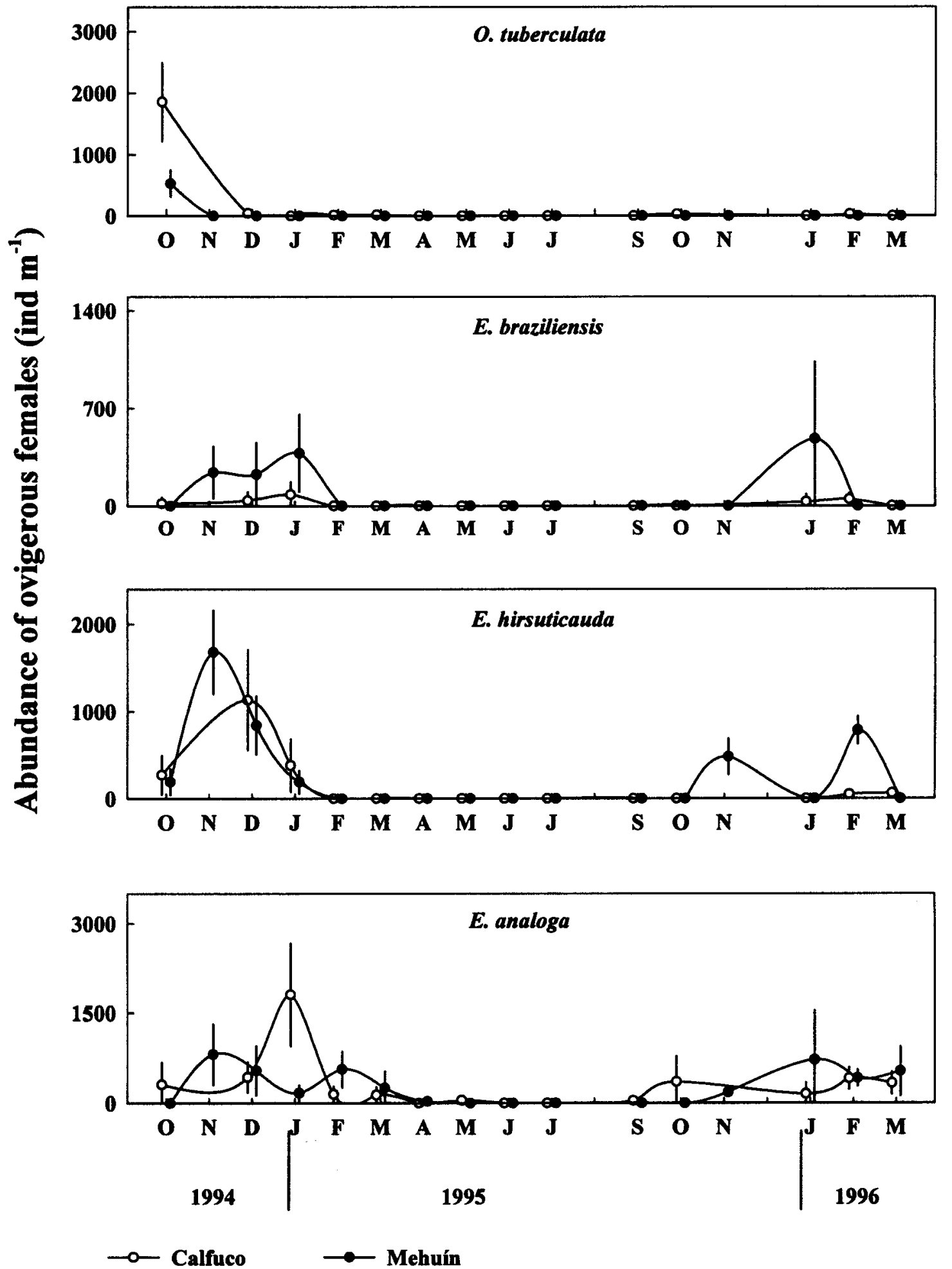

Fig. 2: Temporal variability in abundances of ovigerous females of $O$. tuberculata, E. braziliensis, E. hirsuticauda and E. analoga at the beaches of Calfuco and Mehuín. The values are means \pm SD.

Variabilidad temporal en las abundancias de hembras ovígeras de O. tuberculata, E. braziliensis, E. hirsuticauda y E. analoga en las playas de Calfuco y Mehuín. Los valores son promedios \pm DE. 


\section{TABLE 4}

Results of the two-way analysis of variance carried out to test for differences in abundances of ovigerous females of $O$. tuberculata E. braziliensis, E. hirsuticauda and E. analoga at the beaches of Calfuco and Mehuín

Resultados de los análisis de varianza de dos vías realizados para evaluar diferencias en las abundancias de hembras ovígeras de O. tuberculata E. braziliensis, E. hirsuticauda y E. analoga en las playas de Calfuco y Mehuín

\begin{tabular}{|c|c|c|c|c|}
\hline & Degree of freedom & Mean of squares & F-ratio & P-value \\
\hline \multicolumn{5}{|l|}{ O. tuberculata } \\
\hline Beach & 1 & 1.36 & 8.64 & 0.0040 \\
\hline Months & 13 & 7.14 & 45.44 & 0.0000 \\
\hline Beach $\mathrm{x}$ months & 13 & 0.18 & 1.12 & 0.3460 \\
\hline Error & 116 & 0.16 & & \\
\hline \multicolumn{5}{|l|}{ E. braziliensis } \\
\hline Beach & 1 & 0.44 & 1.25 & 0.2660 \\
\hline Months & 13 & 3.47 & 9.82 & 0.0000 \\
\hline Beach x months & 13 & 0.78 & 2.22 & 0.0127 \\
\hline Error & 116 & 0.35 & & \\
\hline \multicolumn{5}{|l|}{ E. hirsuticauda } \\
\hline Beach & 1 & 0.001 & 0.004 & 0.9488 \\
\hline Months & 13 & 12.27 & 54.42 & 0.0000 \\
\hline Beach x months & 13 & 0.52 & 2.33 & 0.0087 \\
\hline Error & 116 & 0.23 & & \\
\hline \multicolumn{5}{|l|}{ E. analoga } \\
\hline Beach & 1 & 3.65 & 5.55 & 0.0202 \\
\hline Months & 13 & 10.77 & 16.36 & 0.0000 \\
\hline Beach x months & 13 & 1.78 & 2.70 & 0.0023 \\
\hline Error & 116 & 0.66 & & \\
\hline
\end{tabular}

the same month (October) at both beaches (Fig. 3 ). While the total mean abundance of juveniles of $O$. tuberculata was significantly higher $(\mathrm{P}<$ 0.001 , Table 5) at Calfuco $\left(4,109\right.$ ind $\left.\mathrm{m}^{-1}\right)$ as compared with Mehuín $\left(1,283\right.$ ind $\left.\mathrm{m}^{-1}\right)$, those of E. braziliensis and E. hirsuticauda were significantly higher $(\mathrm{P}=0.0002$ and 0.0113 , respectively, Table 5) at Mehuín (71 and 110 ind $\mathrm{m}^{-1}$ versus 9 and 68 ind $\mathrm{m}^{-1}$, respectively). The total mean abundance of juveniles of $E$. analoga was also significantly higher $(\mathrm{P}=0.0001$, Table 5) at Mehuín $\left(12,511\right.$ ind $\left.\mathrm{m}^{-1}\right)$ as compared with Calfuco $\left(4,113\right.$ ind $\left.\mathrm{m}^{-1}\right)$. The results of the twoway ANOVA's showed that the abundances of juveniles of $O$. tuberculata, E. braziliensis, $E$. hirsuticauda and $E$ analoga varied significantly ( $\mathrm{P}<0.05)$ with beaches and time (months); we also detected significant interactions between month of sampling and beach sampled for each species (Table 5).

\section{Growth}

The non-linear fitting of the VBGF for the growth of $O$. tuberculata, E. braziliensis and $E$ hirsuticauda, explained 94-99 \% of the variance in the data (Table 6). Thus, most of the growth parameters of these species were significant $(\mathrm{P}<0.05)$ or close to the significance level used in this study (0.05). The parameters not within the 0.05 significance level, were $\mathrm{t}_{0}$ for $O$. tuberculata at the intermediate beach of Calfuco $(\mathrm{P}=0.052)$ and $\mathrm{K}$ for E. braziliensis and E. hirsuticauda at the dissipative beach of Mehuín $(P=0.052$ and 0.057 , respectively) (Table 6).

The growth curves generated by VBGF for O.tuberculata were not significantly different $(\mathrm{P}=0.057)$ (Fig. 4), even when the values of $\mathrm{L} \infty$, maximum body size observed and $\mathrm{K}$ were higher at Calfuco (Table 6). The seasonality in 

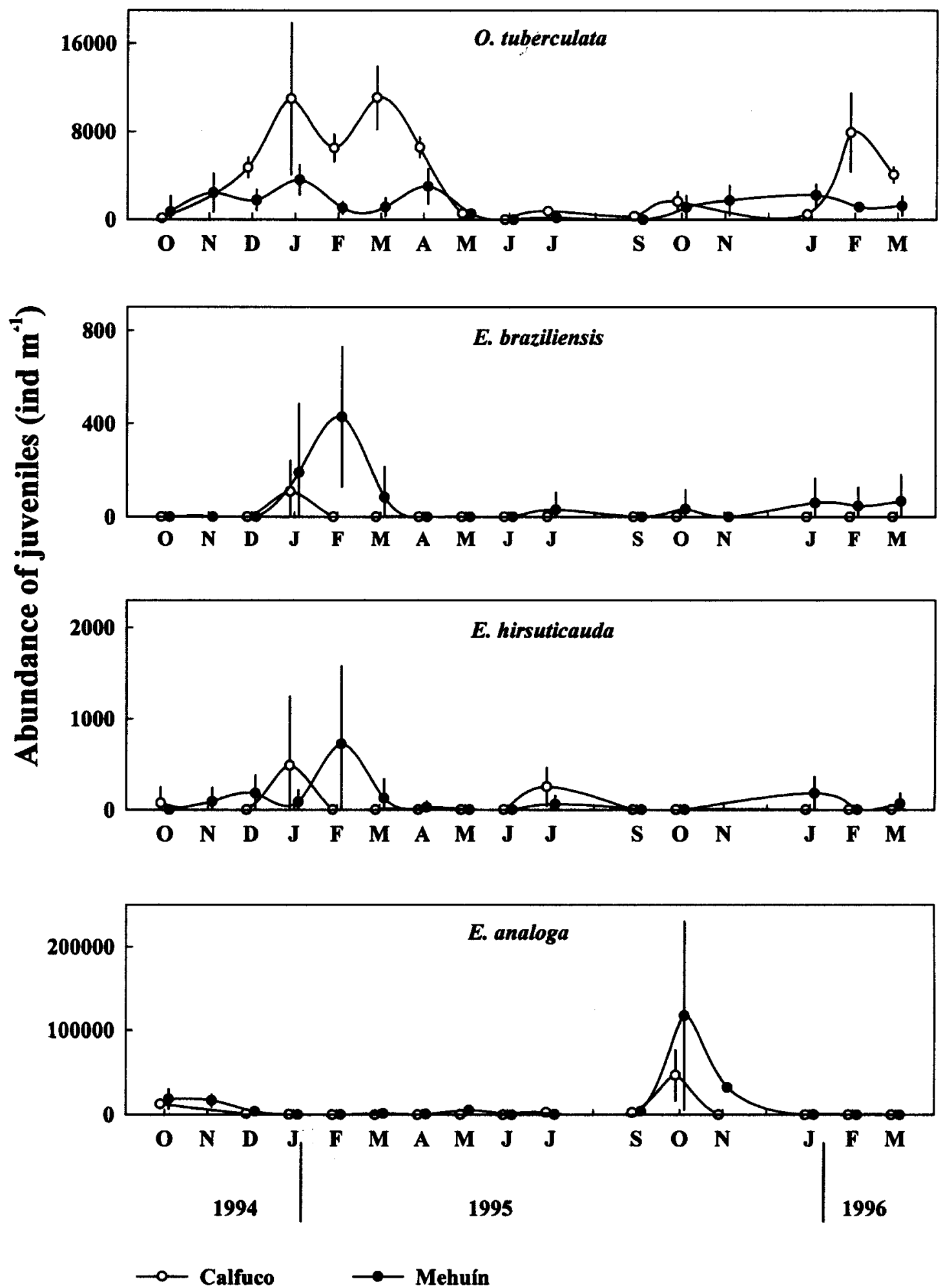

Fig. 3: Temporal variability in abundances of juveniles of O. tuberculata, E. braziliensis, E. hirsuticauda and E. analoga at the beaches of Calfuco and Mehuín. The values are means \pm SD.

Variabilidad temporal en las abundancias de juveniles de O. tuberculata, E. braziliensis, E. hirsuticauda y E. analoga en las playas de Calfuco y Mehuín. Los valores son promedios \pm DE. 


\section{TABLE 5}

Results of the two-way analysis of variance carried out to test for differences in abundances of juveniles of $O$. tuberculata E. braziliensis, E. hirsuticauda and E. analoga at the beaches of Calfuco and Mehuín

Resultados de los análisis de varianza de dos vías realizados para evaluar diferencias en las abundancias de juveniles de $O$. tuberculata E. braziliensis, E. hirsuticauda y E. analoga en las playas de Calfuco y Mehuín

\begin{tabular}{|c|c|c|c|c|}
\hline & Degree of freedom & Mean of squares & F-ratio & P-value \\
\hline \multicolumn{5}{|l|}{ O. tuberculata } \\
\hline Beach & 1 & 13.76 & 30.87 & 0.0000 \\
\hline Months & 13 & 13.22 & 29.66 & 0.0000 \\
\hline Beach $x$ months & 13 & 0.99 & 2.23 & 0.0122 \\
\hline Error & 116 & 0.45 & & \\
\hline \multicolumn{5}{|l|}{ E. braziliensis } \\
\hline Beach & 1 & 6.21 & 14.43 & 0.0002 \\
\hline Months & 13 & 1.85 & 4.30 & 0.0000 \\
\hline Beach $\mathrm{x}$ months & 13 & 1.08 & 2.52 & 0.0045 \\
\hline Error & 116 & 0.43 & & \\
\hline \multicolumn{5}{|l|}{ E. hirsuticauda } \\
\hline Beach & 1 & 3.83 & 6.63 & 0.0113 \\
\hline Months & 13 & 3.03 & 5.25 & 0.0000 \\
\hline Beach $x$ months & 13 & 2.87 & 4.97 & 0.0000 \\
\hline Error & 116 & 0.58 & & \\
\hline \multicolumn{5}{|l|}{ E. analoga } \\
\hline Beach & 1 & 15.31 & 15.90 & 0.0001 \\
\hline Months & 13 & 20.85 & 21.66 & 0.0000 \\
\hline Beach x months & 13 & 5.10 & 5.30 & 0.0000 \\
\hline Error & 116 & 0.96 & & \\
\hline
\end{tabular}

growth was similar for both populations (values of $\mathrm{C}$ between 0.77 and 0.84 ), with values of WP (0.18-0.36) indicating intra-annual oscillations with minimum growth rates around March (Calfuco) and May (Mehuín). Values of $F^{2}$ were similar for both populations (2.872.63 ) indicating similar growth rates.

The growth curves generated by VBGF for E. braziliensis and E. hirsuticauda were not significantly different between beaches $(\mathrm{P}=$ 0.116 and 0.998 , respectively) (Fig. 4). Growth parameters were also similar for both species from each beach (Table 6). Seasonality (C) in growth was around $0.50-0.60$, with minimum growth in the austral winter; around JulyAugust for E. braziliensis (WP $=0.47-0.54$ ) and around August-September for $E$. hirsuticauda (WP = 0.58-0.68) (Table 6).

The non-linear fitting of the VBGF for the growth of females and males of $E$. analoga, explained $92-99 \%$ of the variance in the data
(Table 7). Thus, most of the growth parameters were significant $(\mathrm{P}<0.05)$, except $\mathrm{K}$ for the females of Mehuín $(\mathrm{P}=0.082)$ (Table 7). The growth curves generated by VBGF for the females of $E$. analoga were significantly different (ARSS, P $<0.001$ ) (Fig. 5). The seasonality in growth of males was stronger than that of females at both beaches $(\mathrm{C}=0.91$ 1.00 for males and 0.50 for females, Table 7). Values of WP for females varied between 0.40 (Calfuco) and 0.66 (Mehuín), indicating minimum growth around June and September, respectively; on the other hand, the values of WP estimated for males were almost the same for both beaches (WP $=0.71-0.72)$ with minimum growth around September (Table 7).

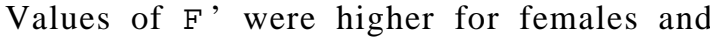
males of the population studied at Mehuín, indicating a higher growth rate for E. analoga at that beach (Table 7). Results of ANCOVA did not show any significant difference $(\mathrm{P}>$ 

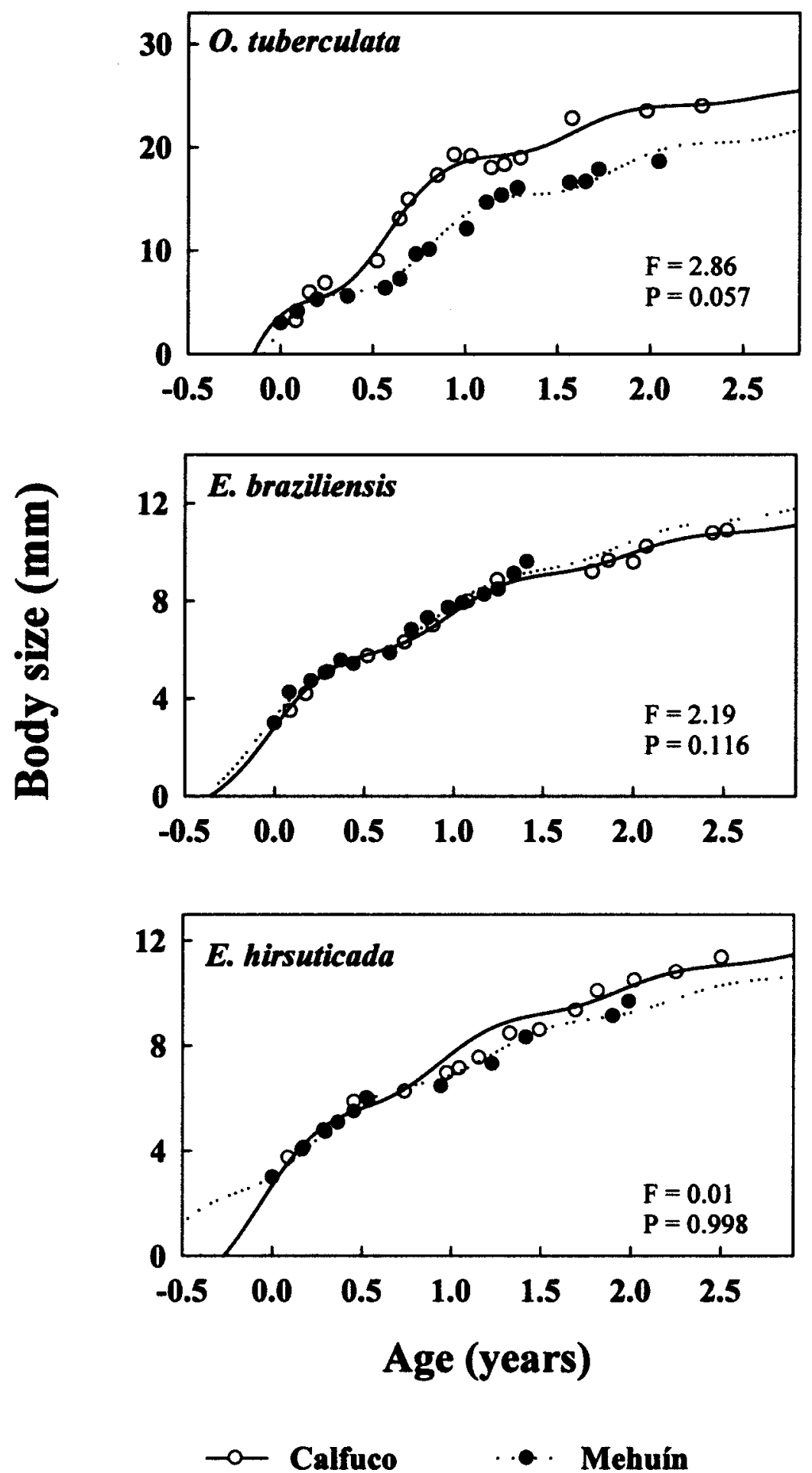

Fig. 4: Growth curves generated by VBGF (see text) for both populations of $O$. tuberculata, E. braziliensis and E. hirsuticauda. The values of $\mathrm{F}$ and $\mathrm{P}$ resulted from the ARSS employed to compare the VBGF between populations (see text).

Curvas de crecimiento generadas por VBGF (ver texto) para ambas poblaciones de O. tuberculata, E. braziliensis y E. hirsuticauda. Los valores de F y P son el resultado de los ARSS usados para comparar las VBGF entre poblaciones (ver texto). 


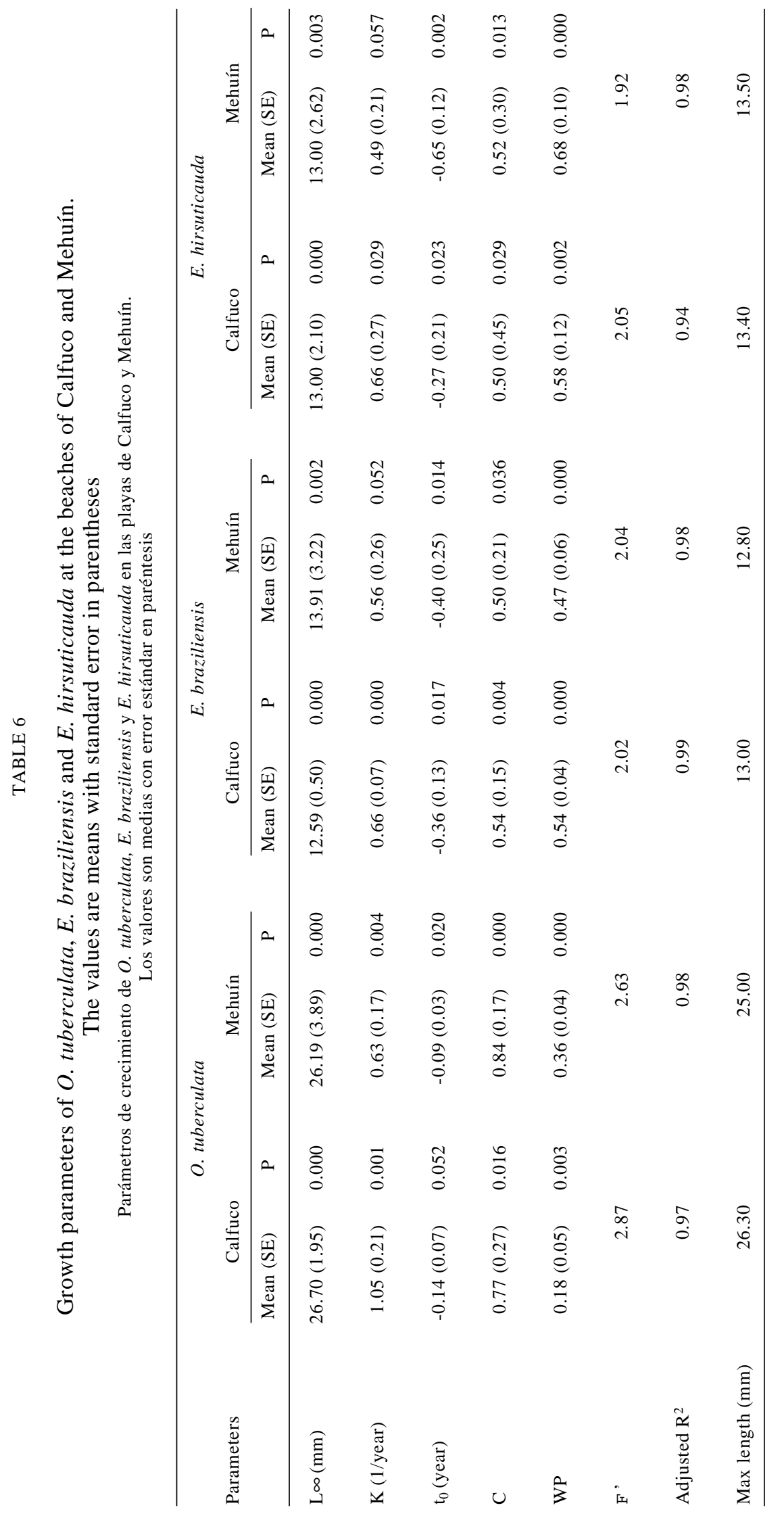


TABLE 7

Growth parameters of E. analoga at the beaches of Calfuco y Mehuín.

The values are means with standard error in parentheses

Parámetros de crecimiento de E. analoga en las playas de Calfuco y Mehuín.

Los valores son medias con error estándar en paréntesis

\begin{tabular}{|c|c|c|c|c|c|c|c|c|}
\hline \multirow{3}{*}{ Parameters } & \multicolumn{4}{|c|}{ E. analoga (females) } & \multicolumn{4}{|c|}{ E. analoga (males) } \\
\hline & \multicolumn{2}{|c|}{ Calfuco } & \multicolumn{2}{|c|}{ Mehuín } & \multicolumn{2}{|c|}{ Calfuco } & \multicolumn{2}{|l|}{ Mehuín } \\
\hline & Mean (SE) & $\mathrm{P}$ & Mean (SE) & $\mathrm{P}$ & Mean (SE) & $\mathrm{P}$ & Mean (SE) & $\mathrm{P}$ \\
\hline $\mathrm{L} \infty(\mathrm{mm})$ & $30.00(6.12)$ & 0.000 & $32.00(8.28)$ & 0.003 & $18.50(2.29)$ & 0.000 & $19.50(2.79)$ & 0.000 \\
\hline $\mathrm{K}$ (1/ year) & $0.50(0.19)$ & 0.022 & $0.66(0.34)$ & 0.082 & $0.50(0.13)$ & 0.003 & $0.51(0.17)$ & 0.016 \\
\hline $\mathrm{t}_{0}($ year $)$ & $-0.13(0.09)$ & 0.016 & $-0.15(0.17)$ & 0.040 & $-0.68(0.05)$ & 0.000 & $-0.75(0.09)$ & 0.000 \\
\hline $\mathrm{C}$ & $0.50(0.39)$ & 0.022 & $0.50(0.44)$ & 0.021 & $0.91(0.17)$ & 0.001 & $1.00(0.39)$ & 0.029 \\
\hline WP & $0.40(0.11)$ & 0.003 & $0.66(0.14)$ & 0.001 & $0.72(0.03)$ & 0.000 & $0.71(0.08)$ & 0.000 \\
\hline $\mathrm{F}^{\prime}$ & 2.65 & & 2.83 & & 2.24 & & 2.47 & \\
\hline Adjusted $\mathrm{R}^{2}$ & 0.92 & & 0.93 & & 0.99 & & 0.95 & \\
\hline Max length (mm) & 28.60 & & 28.50 & & 17.90 & & 18.80 & \\
\hline
\end{tabular}

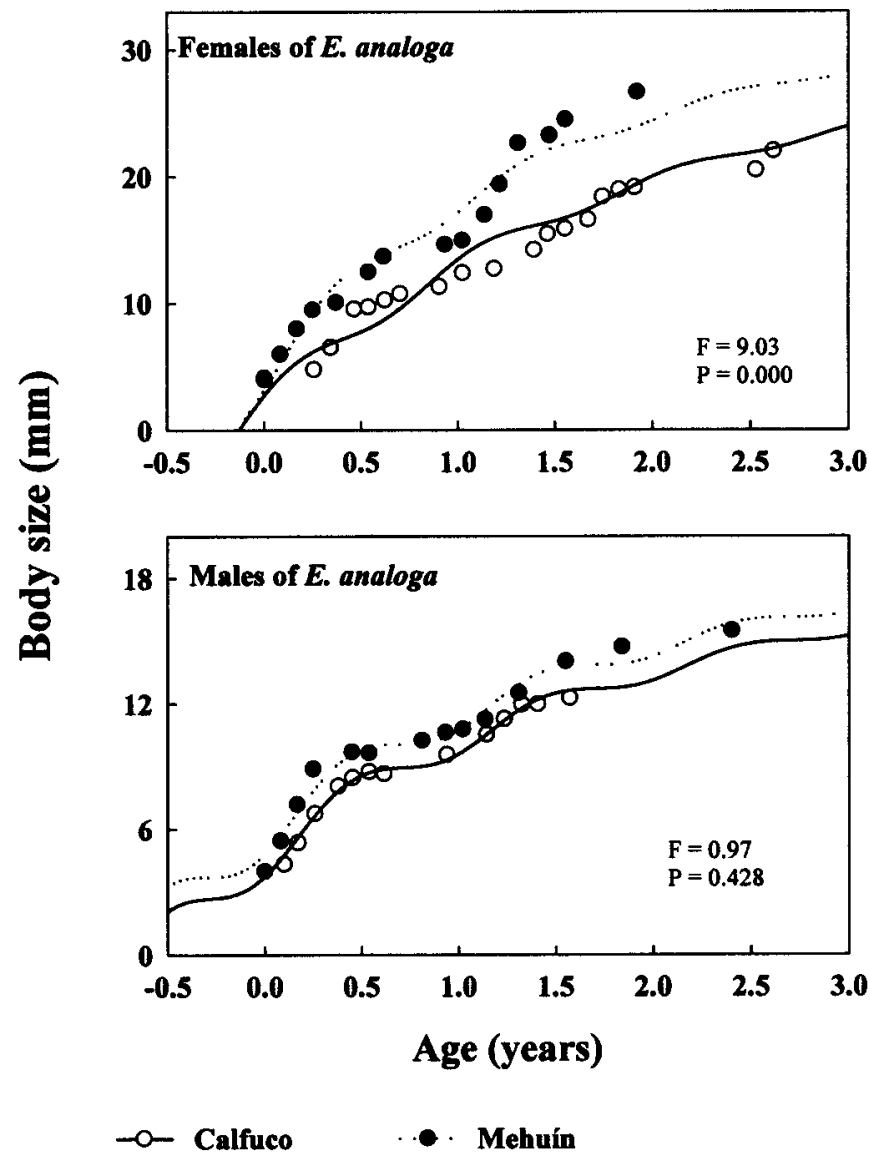

Fig. 5: Growth curves generated by VBGF (see text) for males and females of both populations of E. analoga. The values of $\mathrm{F}$ and $\mathrm{P}$ resulted from the ARSS employed to compare the VBGF between populations (see text).

Curvas de crecimiento generadas por VBGF (ver texto) para ambas poblaciones de E. analoga. Los valores de $\mathrm{F}$ y $\mathrm{P}$ son el resultado de los ARSS usados para comparar las VBGF entre poblaciones (ver texto). 
0.05) in the estimates of the natural mortality calculated for the species populations of each beach (Table 8 ).

\section{DISCUSSION}

The statistical analyses of the physical data revealed that the studied beaches consistently displayed significant differences, either in single features (such as intertidal width, beach face slope and size of sands from the swash zone) or in Dean's parameter, which combines single characteristics (sand fall velocity, wave height and wave period). In other words, during the course of this study, the beach characteristics of Calfuco were modally intermediate, while Mehuín was modally dissipative. Thus, intersite differences were large enough to provide an adequate framework to test our hypothesis. Even though, the conclusions of this study must be viewed within the following perspective: actually, beach morphodynamic types were not replicated since just one beach of each type (i.e., intermediate versus dissipative) were sampled.

The analyses of temporal variability in population abundances of the crustacean macroinfauna showed the following patterns: (i) the almost supralittoral talitrid $O$. tuberculata showed higher population abundances at the intermediate beach of Calfuco as compared to the dissipative site of Mehuín, (ii) the mid shore cirolanid isopods E. braziliensis and $E$. hirsuticauda had significantly higher population abundances at the dissipative beach of Mehuín, and (iii) the lower shore anomuran crab $E$. analoga showed higher population abundances at the intermediate beach of Calfuco. Thus, only the trend shown by the population abundances of the cirolanid isopods agreed with the predictions of the swash exclusion hypothesis; i.e., higher population abundances at dissipative beaches as compared with intermediate ones (cf. McLachlan et al. 1993, 1996, 1998).

Earlier studies showed that swash features associated to Calfuco and Mehuin were different (Ramirez, 1994). Dissipative beaches have wider swash zones, lower frequency of swashes and lower number of effluent line crossings as compared with intermediate and reflective beaches (McArdle \& McLachlan 1991, 1992, Jaramillo et al. 2000). As hypothesized in this study, swash features should influence more those species directly affected by swashes when moving or feeding over the beach face (E. analoga and the cirolanid isopods) than those living in the supralittoral above the swash limit ( $O$. tuberculata). As stated by McLachlan et al. (1993), the swash exclusion hypothesis refers primarily to the animals living in the active swash zone (McLachlan et al. 1993). Thus, it is not surprising that the population abundances of the amphipod $O$. tuberculata were not higher at the dissipative site as would be expected for a true swash zone organism. Since the burrowing zone of $O$. tuberculata is located further up that zone, swash features do not affect population abundances of this talitrid amphipod. This is another example of an upper shore sandy beach organism with lower population abundances towards the dissipative conditions. Gómez \& Defeo (1999) and Defeo et al. (1997) found at the coast of Uruguay, that the population abundances of the talitrid amphipod Pseudorchestoidea brasiliensis

\section{TABLE 8}

Estimates of instantaneous mortality rate (M) of O. tuberculata, E. braziliensis, E. hirsuticauda and E. analoga at the beaches of Calfuco and Mehuín. Results of ANCOVA are also given

Estimaciones de la tasa instantánea de mortalidad (M) de O. tuberculata, E. braziliensis, E. hirsuticauda y E. analoga en las playas estudiadas. Se presentan también los resultados del ANCOVA

\begin{tabular}{|c|c|c|c|c|c|c|c|c|c|c|}
\hline & \multicolumn{2}{|c|}{ O. tuberculata } & \multicolumn{2}{|c|}{ E. braziliensis } & \multicolumn{2}{|c|}{ E. hirsuticauda } & \multicolumn{2}{|c|}{ Females of E. analoga } & \multicolumn{2}{|c|}{ Males of E. analoga } \\
\hline & Calfuco & Mehuín & Calfuco & Mehuín & Calfuco & Mehuín & Calfuco & Mehuín & Calfuco & Mehuín \\
\hline Intercept & 8.46 & 9.08 & 6.85 & 8.69 & 7.76 & 10.94 & 11.36 & 6.66 & 9.20 & 10.49 \\
\hline $\begin{array}{l}\text { Mortality } \\
\text { (M 1/year) }\end{array}$ & 2.33 & 2.14 & 1.48 & 1.32 & 1.56 & 1.41 & 2.04 & 1.68 & 1.46 & 1.97 \\
\hline $\mathrm{R}^{2}$ & 0.81 & 0.92 & 0.93 & 0.97 & 0.97 & 0.93 & 0.94 & 0.73 & 0.80 & 0.95 \\
\hline ANCOVA & \multicolumn{2}{|c|}{$\begin{array}{c}\mathrm{F}_{1,37}=0.44 \\
\mathrm{P}=0.510\end{array}$} & \multicolumn{2}{|c|}{$\begin{array}{c}\mathrm{F}_{1,18}=0.47 \\
\mathrm{P}=0.337\end{array}$} & \multicolumn{2}{|c|}{$\begin{array}{c}\mathrm{F}_{1,16}=0.77 \\
\mathrm{P}=0.392\end{array}$} & \multicolumn{2}{|c|}{$\begin{array}{c}\mathrm{F}_{1,32}=1.65 \\
\mathrm{P}=0.208\end{array}$} & \multicolumn{2}{|c|}{$\begin{array}{c}\mathrm{F}_{1,20}=3.59 \\
\mathrm{P}=0.073\end{array}$} \\
\hline
\end{tabular}


(Dana, 1853) and the cirolanid isopod $E$. braziliensis were higher at a coarse grain reflective beach as compared to a fine sand dissipative beach. Independent of beach types, high population abundances of upper shore arthropods have been also found to be strongly related to amount of algal wrack stranded on beaches. For example, Dugan et al. (2000) found that the abundances of talitrid amphipods (Megalorchestia spp.) and several species of beetles were positively correlated with the cover of algal wrack on the mainland coast and several islands of southern California. Thus, the higher population abundances of $O$. tuberculata at the intermediate site of Calfuco (and also the higher abundances of juveniles and the trend of higher growth rate at that beach, see below) can probably be related to the higher amount of algal wrack commonly seen there as compared with the beach of Mehuín (unpublished observations). As shown by Duarte (1974), $O$. tuberculata is the main consumer of algal wracks on sandy beaches of southern Chile.

The higher population abundances of the cirolanid isopods at the dissipative beach of Mehuín suggest that beach and swash characteristics do indeed influence population abundances of these organisms; i.e., a wider swash zone (cf. Ramírez 1994) would probably favors the tidal migration of these isopods. These results are the opposite to that reported for E. braziliensis in two Uruguayan beach (Defeo \& Martínez 2003), where this species occurs in high abundances in a reflective beach. In contrast to the patterns shown by the cirolanid isopods, the population abundance of the tidal migrant E. analoga was higher at the intermediate beach of Calfuco. These results contradict the swash exclusion hypothesis which predicts that beaches located at or closer to the dissipative end of the spectrum are more beneficial habitats for suspension feeders (McLachlan et al. 1993) such as E. analoga. However, snapshot studies carried out at the Pacific coast of North and South America, show that this anomuran crab is not consistently related to beach morphodynamic types. Dugan \& Hubbard (1994) found that in sandy beaches of southern California, E. analoga had similar population abundances at reflective and intermediate beaches. Similarly, Jaramillo \& Lastra (2001) and Jaramillo et al. (2001) showed that on the Chilean coast, E. analoga displays the highest population abundances at intermediate beaches such as Calfuco. In some intermediate beaches, estimations of mean population abundances of $E$. analoga have been found to be 4-6 times higher than in dissipative sites (Jaramillo et al. 2001). Consequently, population abundances of this anomuran crab seem to be independent of physical features associated with beach morphodynamic types. As stated by Dugan \& Hubbard (1996), the noninfluence of beach morphodynamics on the population abundances of E. analoga could contribute to the wide distribution of this species on sandy beaches of different coasts. In other words, E. analoga can be considered as a generalist species inhabiting over a wide range of morphodynamic beach types.

The ovigerous females of $O$. tuberculata, $E$. braziliensis, E. hirsuticauda and E. analoga showed their maximum abundances at similar periods on both beaches (spring-summer months), suggesting that beach type do not affect the reproductive period of these species, a similar conclusion to that found when periods of maximum abundances of juveniles are compared. The growth parameters of $O$. tuberculata, E. braziliensis and E. hirsuticauda did not show differences between the populations inhabiting the two different morphodynamic beach types studied. Nevertheless, the growth curve of $O$. tuberculata was higher at the intermediate beach of Calfuco. As stated above for the higher population abundances of this amphipod at this site, a trend of higher grow rate is expected due to the higher input of algal wrack in Calfuco. On the other hand, growth curves and growth parameters of E. analoga were higher at the dissipative site of Mehuín, even when the statistical analyses showed that only growth curves of females were significantly different between beaches. A non-consistent trend was also found for Emerita brasiliensis on the coast of Uruguay by Defeo et al. (2001): these authors found that males had higher growth in a reflective beach as compared to a dissipative site, while females grew faster in the dissipative site. Finally, natural mortalities of O. tuberculata, E. braziliensis, E. hirsuticauda and E. analoga did not differ significantly between beaches; another fact which does not agree with the swash exclusion hypothesis which predicts lower mortalities towards the dissipative type of beach.

In summary, the results of this study support earlier conclusions (Dugan et al. 1994, Dugan \& Hubbard 1996, Gómez \& Defeo 1999, Defeo et al. 2001) in the sense that spatial variability in population biology of sandy beach organisms might not necessarily to be explained by beach morphodynamics. Nevertheless, it is necessary to have in mind that more extreme comparisons, like for example populations 
inhabiting fully dissipative beaches as compared with that of fully reflective beaches, could result in differences in population abundances or other biological traits. In other words, the study of a wider spectrum of beach types, would probably tell that some species are best adapted to the dissipative extreme, others to the reflective end, or others may well cope over the whole range of beach types, and be generalists inhabiting the full range of swash features which occurs along that whole beach range. Even though, other physical factors, such as temperature, salinity, content of chlorophyll $a$ in the surf zone waters, along shore distance and amount of algal wrack stranded on beaches may be also important in the explanation of spatial variability in population abundances and natural history of sandy beach species (e.g., Dugan et al. 1994, Dugan \& Hubbard 1996, Dugan et al. 2000). Thus, future studies should include not only detailed studies of sand and wave characteristics, but also surf zone features, near shore proccesses and input of algal wrack which may well regionally affect recruitment and subsequent population abundances.

\section{ACKNOWLEDGEMENTS}

We thank P. Quijón, M. González, M. H. Avellanal, C. Añazco and M. Mercado for assistance in the field and laboratory work. We especially thank Omar Defeo for his continuous help in growth analyses of crustaceans and for the critical review and improvement of an earlier manuscript. This study was supported by a European Union Contract (CI 1-CT 93-0338). Data analyses and writing of the manuscript was made possible thanks to the financial support provided to HC by a FONDECYT grant $\mathrm{N}^{\circ} 2010018$, to EJ by a FONDAP grant (Program 3) and a FONDECYT grant $\mathrm{N}^{\circ}$ 1000423 , and to CD by a FONDAP grant (Program 3).

\section{LITERATURE CITED}

CHEN Y, DA JACKSON, \& HH HARVEY (1992) A comparison of Von Bertalanffy and polynomial functions in modelling fish growth data. Canadian Journal of Fisheries and Aquatic Sciences 49: 1228-1235.

CONTRERAS H, E JARAMILLO \& P QUIJÓN (2000) Natural history of Emerita analoga (Stimpson) (Anomura, Hippidae) in a sandy beach of northern Chile. Revista Chilena de Historia Natural 73: 705-715.

DEFEO O, J GÓMEZ \& D LERCARI (2001) Testing the swash exclusion hypothesis in sandy beach populations: the mole crab Emerita braziliensis in Uruguay. Marine Ecology Progress Series 212: $159-170$

DEFEO O, A BRAZEIRO, A DE ALAVA \& G RIESTRA (1997) Is a sandy beach macrofauna only physically controled? Role of substrate and competition in isopods. Estuarine Coastal and Shelf Science 45: 453-462.

DEFEO O \& G MARTÍNEZ (2003) The habitat harshness hypothesis revisited: life history of the isopod Excirolana braziliensis in sandy beaches with contrasting morphdinamics. Journal of the Marine Biological Association of the United Kingdom 83: 331-340.

DUARTE W (1974) Orchestoidea tuberculata Nicolet, 1849 como organismo desintegrador de algas (Crustacea, Amphipoda, Talitridae). Noticiario Mensual del Museo Nacional de Historia Natural (Chile) 19: 3-9.

DUGAN J \& D HUBBARD (1996) Local variation in population of the sand crab Emerita analoga on sandy beaches in southern California. Revista Chilena de Historia Natural 69: 579-588.

DUGAN J, D HUBBARD, D MARTIN, J ENGLE, D RICHARDS, G DAVIS, K LAFFERTY \& R AMBROSE (2000) Macrofauna communities of exposed sandy beaches on the southern California mainland and Channel Islands. Proceedings of the Fifth California Island Symposium. OCS Study, MMS 99-0038: 339-346.

EMERY KO (1938) Rapid method of mechanical analysis of sands. Journal of Sedimentary Petrology 8: 105-111.

EMERY KO (1961) A simple method of measuring beach profiles. Limnology and Oceanography 6:90-93.

FOLK R (1980) Petrology of sedimentary rocks. Hemphill Publishing Co., Austin, Texas, USA. 188 pp.

GAYANILO FC JR, P SPARRE \& D PAULY (1996) The FAO-ICLARM stock assessment tools (FISAT) user's guide. FAO Computerized Information Series $N^{\circ} 8$. Rome, Italy. 126 pp.

GIBBS RJ, MD MATHEWS \& DA LINK (1971) The relationship between sphere size and settling velocity. Journal of Sedimentary Petrology 41: 7-18.

GÓMEZ J \& O DEFEO (1999) Life history of the sandhopper Pseudorchestoidea brasiliensis (Amphipoda) in sandy beaches with contrasting morphodynamics. Marine Ecology Progress Series 182: $209-220$

HOENIG JM \& RC HANUMARA (1982) A statistical study of a seasonal growth model for fishes. Technical Report, Department of Computer Science and Statistics, University of Rhode Island, Kingston, Rhode Island, USA. 91 pp.

JARAMILLO E (2001) The sand beach ecosystem of Chile. In: Seeliger U \& B Kjerfve (eds) Coastal marine ecosystems of Latin America: 219-227. SpringerVerlag, Berlin, Germany.

JARAMILLO E \& S FUENTEALBA (1993) Down-shore zonation of two cirolanid isopods during two springneap tidal cycles in a sandy beach of south central Chile. Revista Chilena de Historia Natural 66: 439-454.

JARAMILLO E \& McLACHLAN (1993) Community and population response of the macroinfauna to physical factors over a range of exposed sandy beaches in south-central Chile. Estuarine Coastal and Shelf Science 37: 615-624.

JARAMILLO E \& M LASTRA (2001) Suspension feeders on sandy beaches. In: Reise K (ed) Ecological comparisons of sedimentary shores: 61-72. Springer-Verlag, Berlin, Germany. 
JARAMILLO E, F CARRASCO, P QUIJÓN, M PINO \& H CONTRERAS (1998) Distribución y estructura comunitaria de la macroinfauna bentónica en la costa del norte de Chile. Revista Chilena de Historia Natural 71: 459-478.

JARAMILLO E, J DUGAN \& H CONTRERAS (2000) Abundance, population structure, tidal movement and burrowing rate of Emerita analoga (Stimpson, 1857) (Anomura, Hippidae) at a disssipative and a reflective sandy beach in south central Chile. Marine Ecology-Pubblicazioni Della Stazione Zoologica di Napoli 21: 113-127.

JARAMILLO E, H CONTRERAS, C DUARTE \& P QUIJÓN (2001) Relationships between community structure of the intertidal macroinfauna and sandy beach characteristics along the Chilean coast. Marine Ecology, Pubblicazioni Della Stazione Zoologica di Napoli 22: 323-342.

KENNEDY F (1997) The locomotor behaviour of peracarid crustaceans on wave-exposed sandy beaches of Chile. Ph.D. Thesis, University of Wales, Bangor, Menai Bridge, United Kingclom. 213 pp.

McARDLE SB \& A McLACHLAN (1991) Dynamics of the swash zone and effluent line on sandy beaches. Marine Ecology Progress Series 76: 91-99.

McARDLE SB \& A McLACHLAN (1992) Sand beach ecology: swash features relevant to the macrofauna. Journal of Coastal Research 8: 398-407.

McLACHLAN A (1990) Dissipative beaches and macroinfauna communities on exposed intertidal sand. Journal of Coastal Research 6: 57-71.

McLACHLAN A \& E JARAMILLO (1995) Zonation on sandy beaches. Oceanography and Marine Biology: an Annual Review 33: 305-335.

McLACHLAN A, E JARAMILLO, TE DONN \& F WESSELS (1993) Sandy beach macrofauna communities and their control by the physical environment: a geographical comparison. Journal of Coastal Research 15: 27-38.

McLACHLAN A, E JARAMILLO, O DEFEO, J DUGAN, A DE RUYCK \& P COETZEE (1995) Adaptations of bivalves to different beach types. Journal of Experimental Marine Biology and Ecology 187: 147-160.

McLACHLAN A, A DE RUYCK \& N HACKING (1996) Community structure of sandy beaches: patterns of richness and zonation in relation to tide range and latitude. Revista Chilena de Historia Natural 69: 451-467.

McLACHLAN A, M FISHER, HN AL-HABSI, SS ALSHUKAIRI \& A AL-HABSI (1998) Ecology of sandy beaches in Oman. Journal of Coastal Conservation 4: 181-190.
MARQUARDT DW (1963) An algorithm for least squares estimation of parameters. Journal of the Society of Industrial and Applied Mathematics 11: 431-441.

PAULY D \& G GASCHÜTZ (1979) A simple method for fitting oscillating length growth data, with a program for pocket calculators. ICES CM 1979/G $26 \mathrm{pp}$ (mimeo).

PAULY D, J MOREAU \& N ABAD (1995) Comparisons of age-structured and length-converted catch curves of brown trout Salmo trutta in two French rivers. Fisheries Research 22: 197-204.

PAULY D \& JL MUNRO (1984) Once more on the comparison of growth in fish and invertebrates. Fishbyte 1: 21.

RAMIREZ S (1994) Climas de Resaca y su influencia sobre la distribución de Emerita analoga (Stimpson) (Custacea: Anomura) en playas arenosas del centrosur de Chile. Tesis de Biología Marina, Universidad Austral de Chile, Valdivia, Chile. 27 pp.

SEWARD-THOMPSON B \& J HAILS (1973) An appraisal on the computation of statistical parameters in grain size analysis. Sedimentology 11: 83-98.

SHRAGER RI (1972) Regression with linear constraints: an extension of the magnified diagonal method. Journal of the Association for Computing Machinery 17: 446-452.

SOKAL RR \& FJ ROHLF (1995) Biometry: the principles and practice of statistics in biological research. W.H. Freeman, New York, New York, USA. 877 pp.

SOMERS IF (1988) On a seasonally oscillating growth function. Fishbyte 6: 8-11.

SHORT AD \& LD WRIGHT (1983) Physical variability of sandy beaches. In: McLachlan A \& T Erasmus (eds) Sandy beaches as ecosystems: 133-144. W. Junk, The Hague, The Netherlands.

SPARRE P (1989) What is the optimum interval class size for length-frequency analysis? Fishbyte 7: 23.

SPARRE P, E URSIN \& VC VENEMA (1989) Introduction to tropical fish assessment. Part I. Manual. FAO Fisheries Technical Paper (306.1), Rome, Italy. 337 pp.

SPARRE P \& VC VENEMA (1995) Introducción a la evaluación de recursos pesqueros tropicales. FAO, Documento Técnico de Pesca (306/1), Valparaíso, Chile. $420 \mathrm{pp}$.

VAKILY JM (1990) Determination and comparison of growth in bivalves, with emphasis on the tropics and Thailand. Ph.D. Dissertation, Christian-Albrechts-Universität, Kiel, Germany. 116 pp.

WOLFF M (1989) A proposed method for standardization of the selection of class intervals for length frequency analysis. Fishbyte $7: 5$. 